\title{
Research Paper: \\ Effect of Sodium Benzoate on Apoptosis and Mitochondrial Mem- brane Potential After Aluminum Toxicity in PC-12 Cell Line
}

\author{
Marzieh Rashedinia ${ }^{1,2}$ (D), Jamileh Saberzadeh ${ }^{3,4}$ (D), Forouzan Khodaei ${ }^{2}$ (D), Najmeh Mashayekhi Sardoei², Mahshid Alimohammadi ${ }^{2}$ (D), Rita \\ Arabsolghar ${ }^{3,4^{*}}$ (iD)
}

1. Medicinal Plants Processing Research Center, Shiraz University of Medical Sciences, Shiraz, Iran.

2. Department of Pharmacology and Toxicology, Faculty of Pharmacy, Shiraz University of Medical Sciences, Shiraz, Iran.

3. Diagnostic Laboratory Sciences and Technology Research Center, School of Paramedical Sciences, Shiraz University of Medical Sciences, Shiraz, Iran

4. Department of Medical Laboratory sciences, School of Paramedical Sciences, Shiraz University of Medical Sciences, Shiraz, Iran.

\begin{tabular}{|l|l|l}
\hline $\begin{array}{c}\text { Use your devic to scan } \\
\text { and read the article online }\end{array}$ & $\begin{array}{l}\text { How to cite this paper Rashedinia M, Saberzadeh J, KhodaeiF, Mashayekhi Sardoei N, Alimohammadi M, Arabsolghar R. Effect } \\
\text { of Sodium Benzoate on Apoptosis and Mitochondrial Membrane Potential After Aluminum Toxicity in PC-12 Cell Line. Iranian } \\
\text { Journal of Toxicology. 2020; 14(4):237-244. http://dx.doi.org/10.32598/ijt.14.4.677.1 }\end{array}$ \\
dol'http://dx.doi.org/10.32598/ijt.14.4.677.1
\end{tabular}

\section{(i) $\$$}

Article info:

Received: 15 Mar 2020

Accepted: 08 July 2020

Online Published: 01 Oct 2020

* Corresponding author:

Rita Arabsolghar, PhD.

Address: Diagnostic Laboratory

Sciences and Technology Research

Center, School of Paramedical Sci-

ences, Shiraz University of Medical

Sciences, Shiraz, Iran.

E-mail: arabsolghar@sums.ac.ir

\section{A B S T RACT}

Background: Sodium benzoate, a food preservative, prevents the growth of fungi and bacteria. Numerous studies have reported the protective effects of sodium benzoate on the nervous system. This study investigated the effect of sodium benzoate on cell apoptosis and mitochondrial function in an aluminum cell toxicity model.

Methods: After $48 \mathrm{hr}$ of treating PC-12 cells with varying concentrations of sodium benzoate $(0.125,0.25$ or $0.5 \mathrm{mg} / \mathrm{ml})$ in the presence of aluminum maltolate $(500 \mu \mathrm{M})$, the cell viability was assessed by MTT assay. The type of cell death (necrosis or apoptosis) was analyzed by flow cytometry (7-ADD/An V-PE staining). Also, rhodamine 123 was used to measure the Mitochondrial Membrane Potential (MMP). The acetylcholinesterase activity (AChE) was assessed by Ellman's method.

Results: It was observed that sodium benzoate inhibited aluminum induced cell death within $48 \mathrm{hr}$. Sodium benzoate at a concentration of $0.5 \mathrm{mg} / \mathrm{ml}$ significantly reduced the apoptotic cells that had been exposed to aluminum. Exposure of PC-12 cells with sodium benzoate and aluminum, increased the AChE activity, although, no significant changes in mitochondrial membrane potential were observed.

Conclusion: Sodium benzoate may provide its protective effects through increased AChE activity and inhibiting apoptosis induced by aluminum toxicity. It is likely that the disruption of MMP is neither involved in the induction of apoptosis by aluminum nor in the protective effect of sodium benzoate.

Keywords: Sodium benzoate, Aluminum, Neurotoxicity, PC-12 cell line, Necrosis and apoptosis, Acetylcholinesterase

\section{Introduction}

he origin and etiology of neurodegenera-

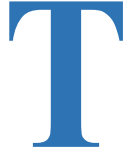

tive disorders, such as Alzheimer's and Parkinson's Diseases (AD, PD) is multifactorial. Some basic metals are believed to contribute to the development of these disorders. One of the metals that is increasing known to play a major role in cell toxicity in the central nervous system is aluminum [1]. This metal may enter the human body via food, drinking water, beverages and medications [2, 3]. Some studies have shown that aluminum induces neuronal death and produces neurofibrillary tangles, as documented by $\mathrm{AD}$ studies $[4,5]$. 
Mitochondria, a vital organelle in eukaryotic cells, have various rolls including cellular energy generation, oxygen consumption, fatty acid metabolism, ions transport and storage, among others. Aluminum toxicity causes mitochondrial dysfunction, such as defective electron transport chain complexes $[6,7]$. There is evidence to suggest that beta amyloids can disrupt mitochondrial functions directly by inducing neuronal death $[8,9]$. Mitochondrial membrane potential (MMP) is reduced due to abundant presence of Reactive Oxygen Species (ROS), secondary to aluminum toxicity in neurons [10]. Further, it is known that the number of mitochondria declines during the development of $\mathrm{AD}$ [11].

Sodium benzoate is a food additive that is largely used due to its bacteriostatic and fungistatic properties under acidic condition [12]. It's use is approved by the U.S. Food and Drug Administration, and there is evidence to show that it is useful to the management of diseases, such as urea cycle disorder in children [13], cognitive impairment in the early phase of $\mathrm{AD}$ and schizophrenic symptoms by inhibiting $\mathrm{D}$ amino acid oxidase [14]. In addition, the protective effects of sodium benzoate have been shown in other diseases, such as multiple myeloma, multiple sclerosis and PD [15].

Acetylcholinesterase (AChE) is an important enzyme that serves in the normal function of cholinergic neurons in the central nervous system [16]. The cholinergic hypothesis has been proposed for the histopathological and biochemical variations of neurotransmitter markers in the brains of patients with $\mathrm{AD}$ [17]. The degeneration of cholinergic neurons has been observed in $\mathrm{AD}$ and inhibition of $\mathrm{AChE}$ activity is known to be the target in the treatment of this disease [18]. Previously, we have showed that sodium benzoate inhibits aluminum toxicity in PC-12 cell line [19]. This study was conducted to explore the role of sodium benzoate in apoptosis, and its impact on MMP and acetylcholinesterase activity cell toxicity with aluminum, as an experimental model of neurodegenerative diseases, such as AD.

\section{Materials and Methods}

Reagents \& chemicals: PC-12 rat pheochromocytoma cells were purchased from Pasteur Institute (Tehran, Iran). Maltol (3-hydroxy-2-methyl-4-pyron), aluminum chloride (AlCl3.6H2O), 5,5'-dithiobis (2-nitrobenzoic acid) (DTNB) and sodium benzoate were bought from Merck Company (Darmstadt, Germany). Rhodamine 123 was obtained from Sigma-Aldrich Company (St. Louis, MO, USA). Also, fetal bovine serum, Dulbecco's modified Eagle's medium (DMEM), horse serum, trypsin, penicillin, and streptomycin were obtained from Gibco BRL Life Technologies (Grand Island, NY, USA).
Preparation of aluminum maltolate complex: Aluminum maltolate (Almal) was prepared according to a previous procedure $[7,19]$. A stock solution $(25 \mathrm{mM})$ of Almal was prepared and sterilized, using a $0.22 \mu \mathrm{M}$ filter.

Cell culture \& treatment: PC-12 cells were cultured in DMEM, containing 10\% heat-inactivated horse serum, $5 \%$ fetal bovine serum, $100 \mathrm{U} / \mathrm{mL}$ penicillin and streptomycin. The cells were incubated at $37^{\circ} \mathrm{C}$ under $5 \% \mathrm{CO} 2$ condition to reach $70-80 \%$ confluency. They were seeded overnight and then treated with Almal $(250,500,750$, or $1000 \mu \mathrm{M})$ or at various concentrations of sodium benzoate $(0.125,0.25$, $0.5,1,1.5,2,2.5$, or $3 \mathrm{mg} / \mathrm{mL}$ ) in Phosphate Buffered Saline (PBS), and incubated at $37^{\circ} \mathrm{C}$ for $48 \mathrm{hr}$. After analyzing the results of the cytotoxicity by 3-(4, 5-dimethylthiazol-2-yl)- 2, 5-diphenyl tetrazolium (MTT) assay, Almal was selected for co-treatment at $500 \mu \mathrm{M}$ concentration with sodium benzoate $(0.125,0.25,0.5$ or $1 \mathrm{mg} / \mathrm{mL})$, and incubated for $48 \mathrm{hr}$.

Cell viability \& apoptosis: After $48 \mathrm{hr}$ of treatment, MTT assay was used to determine the cell viability $\left(10^{3}\right.$ cells/well). The medium was removed and $20 \mu \mathrm{L}$ of MTT solution (5 $\mathrm{mg} / \mathrm{mL}$ in PBS) was added, and incubated for another $4 \mathrm{hr}$ at $37^{\circ} \mathrm{C}$. To dissolve the blue formazan product, $150 \mu \mathrm{L}$ dimethylsulfoxide (DMSO) was added to each well. The absorbance was read at $570 \mathrm{~nm}$ by an automated plate reader (BioTek, Bad Friedrichshall, Germany). Results were reported as percentages of cell viability relative to the untreated cells, as the control group. To determine cell apoptosis in the treated and control groups, we used Annexin V-FITC kit (Dako, catno: k235011). Briefly, after cell culture and treatment, cells were washed in cold PBS, suspended in $1 \mathrm{~mL}$ ice cold binding buffer and added $5 \mu \mathrm{L}$ Annexin V-FITC $+5 \mu \mathrm{L}$ PI to $95 \mu \mathrm{L}$ suspended cells, after gently mixing, incubated for $15 \mathrm{~min}$ in the dark. After adding $400 \mu \mathrm{L}$ binding buffer, all tubes were analyzed with BD flow cytometer.

Measurement of Mitochondrial Membrane Potential (MMP): We used fluorescent dye Rhodamine-123 (Rh-123) for the measurement of MMP [7]. $10 \mu \mathrm{L} \mathrm{Rh-123} \mathrm{was} \mathrm{added}$ to $2 \times 10^{5}$ cells and incubated for $30 \mathrm{~min}$ in the dark at $37^{\circ} \mathrm{C}$. After washing with PBS, the fluorescence intensity was measured, using FLUO-star Omega multifunctional microplate reader (Munster, Germany). The wavelengths for excitation and emission were set at 485 and $525 \mathrm{~nm}$, respectively [20]

Measurement of acetylcholinesterase activity: For measuring AChE activity, we used acethyl thiocholin as the substrate for AChE, as described by Ellman method [21]. Briefly, $3 \times 10^{6}$ cells were seeded in 6-well plates. After $48 \mathrm{hr}$ of treatment, the media was removed and PBS added. Cells were then transferred to tubes for a 5-min centrifugation at $1500 \mathrm{rpm}$. Cell lysate was prepared by sonication, a $50 \mu \mathrm{L}$ 
cell lysate was added to 96-well plate plus $97 \mu \mathrm{L}$ Ellman buffer $(90 \mu \mathrm{L} \mathrm{PBS}+5 \mu \mathrm{L}$ DTNB $+2 \mu \mathrm{L}$ acetyl thiocholin $)$. During the 15-min, absorption changes were recorded by an ELISA reader at $405 \mathrm{~nm}$. The protein content for each cell group was measured by the Bradford method [22] and the enzyme activity was determined.

Statistical analysis: The data from the triplicate, independent experiments are presented as Means \pm SEM. Data analysis was performed using one-way analysis of variance (ANOVA) followed by LSD post-hoc test on SPSS, v. 16. P values of $<0.05$ were considered as the statistical significance.

\section{Results}

Effects on PC-12 cell line: Based on our previous study on cell viability, we used $500 \mu \mathrm{M}$ of Almal concentration, which is closest to LC50, and a co-treatment with non-cytotoxic concentration $(0.125,0.25$ or $0.5 \mathrm{mg} / \mathrm{mL})$ of sodium benzoate [19]. The co-treatment of Almal $(500 \mu \mathrm{M})$ and sodium benzoate confirmed the protective effects of sodium

A

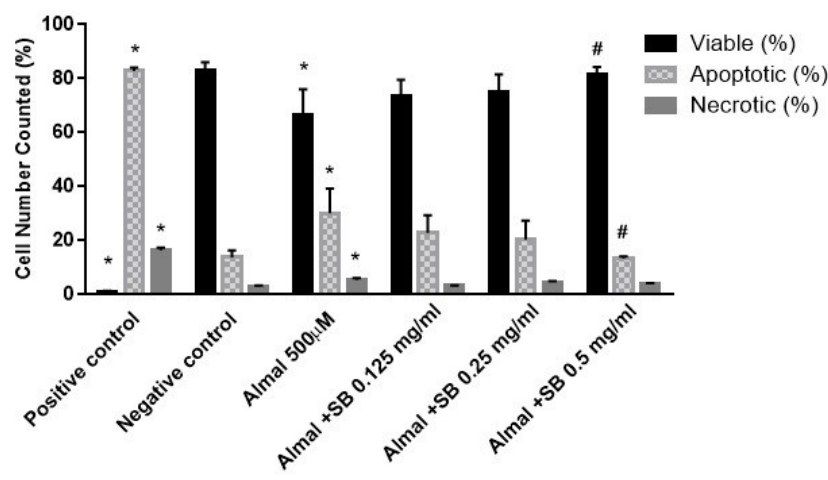

$\mathbf{B}$

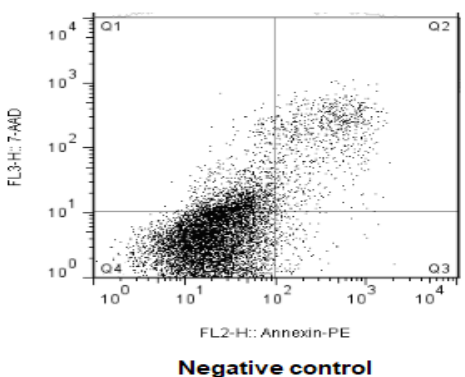

Negative control

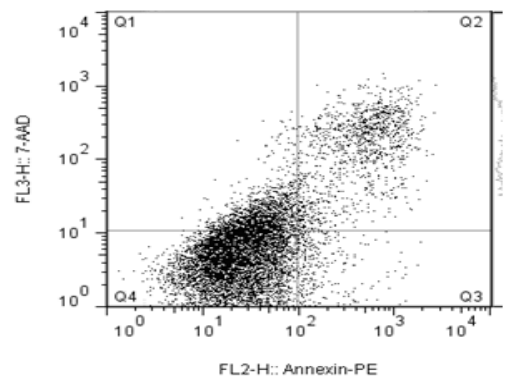

Almal + SB 0.125 mg/m

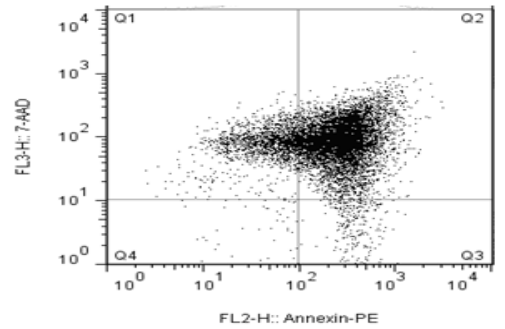

Positive control

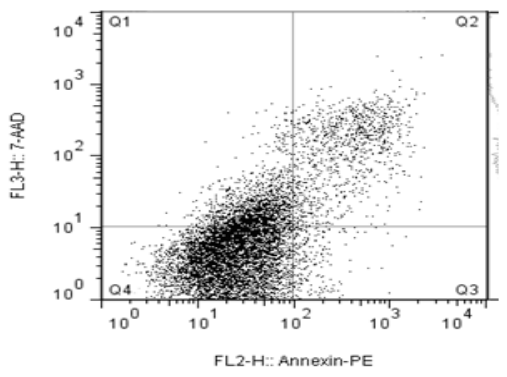

Almal + SB $0.25 \mathrm{mg} / \mathrm{m}$

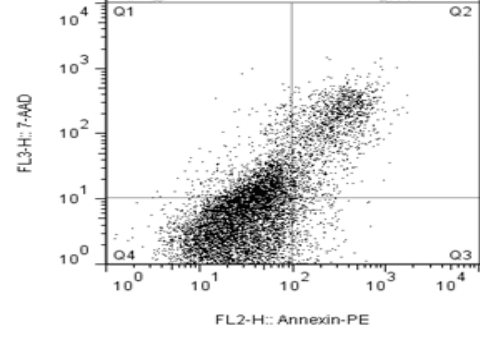

$500 \mu \mathrm{M}$ Almal

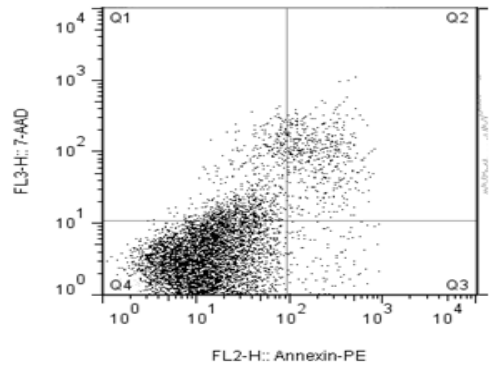

Almal + SB 0.5 mg/ml

Figure 1. Effects of $48 \mathrm{hr}$ of co-treatment with varying concentrations of sodium benzoate and Almal on cell viability

Panel A: Annexin V-PE and 7-AAD staining was represented by flow cytometry. Panel B: Q1= necrotic; Q2: late apoptotic cells; Q3: early stage apoptotic cells; Q4: normal viable cells.

Formaldehyde 3\% used as a positive control. Data are expressed as the Mmeans \pm SEM of triplicate, independent experiments. Significant difference $\mathrm{P}<0.05$ ( ${ }^{*}=$ compared to the negative control group, $\#=$ compared to the Almal group). Almal=aluminum maltolate; $\mathrm{SB}$, sodium benzoate. 


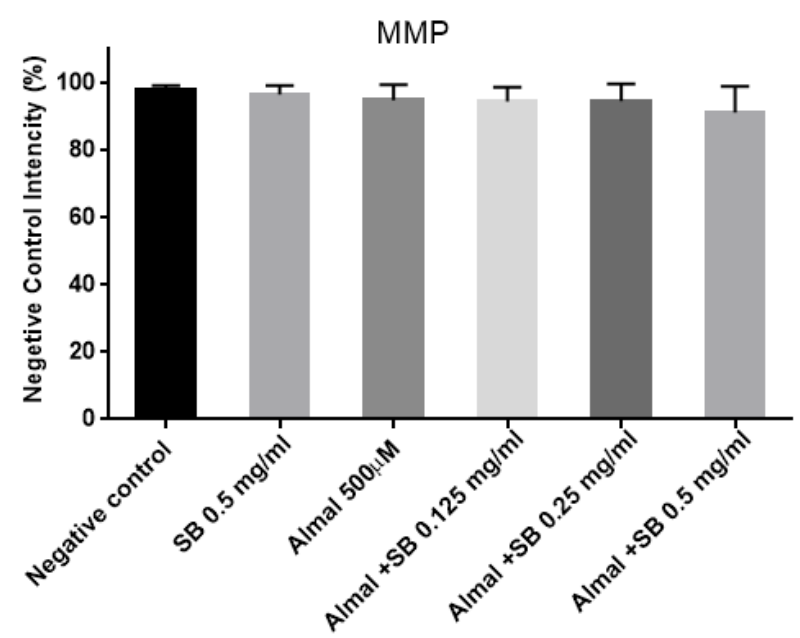

Figure 2. Effects of $48 \mathrm{hr}$ of co-treatment with varying concentrations of sodium benzoate and Almal

Mitochondrial Membrane Potential (MMP) was determined by Rhodamine 123. Data are expressed as the Means \pm SD of triplicate, independent experiments. Almal=Aluminum maltolate; $\mathrm{SB}=$ Sodium benzoate.

benzoate at 0.25 and $0.5 \mathrm{mg} / \mathrm{mL}$ to be significant $(\mathrm{P}<0.05)$ as previously described [19].

Effects on PC-12 Cell Apoptosis: The flow cytometric analysis (Figures $1 \mathrm{~A} \& \mathrm{~B}$ ) showed a decreasing cell viability to $66.37 \pm 0.96 \%$ of the counted cells, increasing percentage of apoptotic $(30.2 \pm 9.7 \%)$ and necrotic $(5.93 \pm 0.2 \%)$ cells after treatment with Almal $(500 \mu \mathrm{M})$. In addition, co-treatment with sodium benzoate significantly increased cell viability and decreased apoptosis only at $0.5 \mathrm{mg} / \mathrm{mL}(\mathrm{P}<0.05)$ without changing the number of necrotic cells compared to those for the Almal experiment.
Effects on Mitochondrial Membrane Potential: Our results did not show any significant decline neither in the MMP of PC-12 cells in Almal treatment vs. the control group, nor in the co-treatment of the cells with varying concentrations of sodium benzoate (Figure 2).

Effects on Acetylcholinesterase Activity: After treating PC-12 cells with Almal, the measured AChE activity showed a decline in the treated group compared to those in the control group. Moreover, co-treatment with sodium benzoate at $0.125,0.25$ or $0.5 \mathrm{mg} / \mathrm{mL}$ increased the AChE activity significantly, compared to those for the Almal group $(\mathrm{P}<0.05)$ (Figure 3).

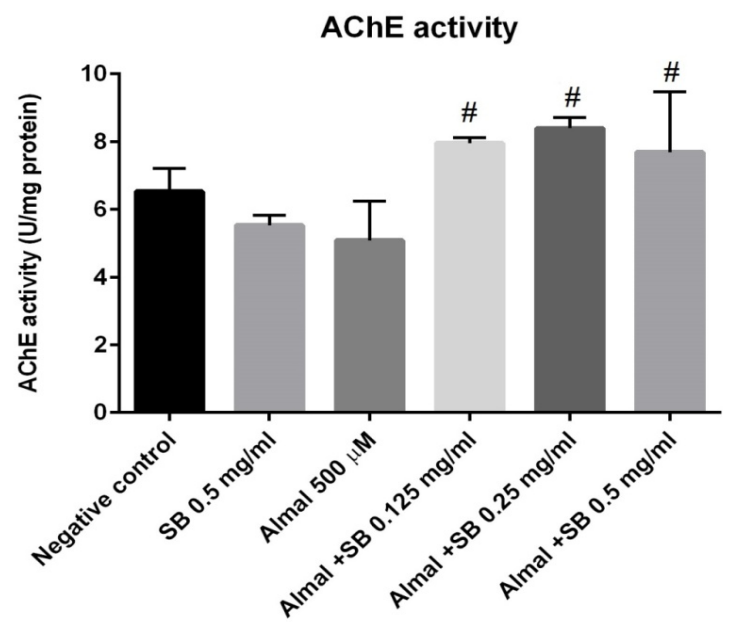

Figure 3. Effects of $48 \mathrm{hr}$ of co-treatment with varying concentrations of sodium benzoate and Almal

Acetyl cholinesterase activity (AChE) was determined by Ellman method. Data are expressed as the Means \pm SD of triplicate independent experiments (\#=compared to the Almal group). Almal=Aluminum maltolate; $\mathrm{SB}=$ Sodium benzoate. 


\section{Discussion}

Since aluminum is increasingly used for numerous commercial purposes, such as healthcare, food packaging and agriculture, continued research is needed to explore its toxicity, and the association with neurodegenerative disorders [14]. Considering the varying effects of sodium benzoate and its potential role in the central nervous system, this study was conducted to investigate these effects. We investigated the effects of sodium benzoate on PC-12 cell line, with a focus on apoptosis, necrosis, mitochondrial membrane potential and acetylcholinesterase activity versus Almal toxicity.

Almal is a lipophilic compound, which is permeable through the cell membranes [23]. Following the metabolism of starch and sucrose, maltolate is produced in large quantities, which can bind to aluminum to produce Almal [24]. Studies have shown the protective effects of sodium benzoate in the management of cognitive disorders, such as $\mathrm{AD}$, Parkinson's Disease and multiple sclerosis [25-28]. Conversely, there are reports suggesting that sodium benzoate may have damaging effects on the mitochondrial functions [29]. Specifically, sodium benzoate may damage the mitochondrial DNA and the proteins involved in the electron transfer chains by generating free radicals [29]. In a study of sodium benzoate on HeLa cells and rat neurons, there were indications of apoptosis and disruption of calcium balance and mitochondrial membrane potentials [29]. In addition, previous studies have indicated that the oral administration of sodium benzoate induced anxiety, motor and memory impairments, increased brain oxidative stress and renal injury in vivo [30-33].

In PC-12 cell line, Almal induced cell death dose dependently, which is consistent with similar findings reported by a previous study [33]. At the concentrations of $0.015,0.25$, or $0.5 \mathrm{mg} / \mathrm{ml}$, sodium benzoate had no deleterious effects on cell growth and the survival rate of PC-12 cells compared to the controls [7]. Therefore, these sodium benzoate concentrations were selected in the current study. This part of the experiments led to similar findings as those reported by a previous study [20]. The authors reported that sodium benzoate did not cause toxic effects on neurons up to a concentration of $1000 \mu \mathrm{g} / \mathrm{mL}$ [27]. Further, co-treatment of PC-12 cells with sodium benzoate and Almal showed that sodium benzoate $(0.125-0.5 \mathrm{mg} / \mathrm{mL})$ inhibited cell death due to the toxicity of Almal after $48 \mathrm{hr}$ of incubation. In our previous study on PC-12 cells [19], sodium benzoate did not show protective effects against cell death at concentrations of 1-3 $\mathrm{mg} / \mathrm{mL}$, based on the MTT Assay. This was probably due to its toxicity at higher doses. The protective effect of sodium benzoate at $0.5 \mathrm{mg} / \mathrm{mL}$ against apoptosis induced by $48 \mathrm{hr}$ of exposure to Almal was significant $(\mathrm{P}<0.05)$. The cell death due to Almal was indeed apoptosis, as has also been reported by another study [34]. The data on the effects of aluminum and sodium benzoate did not suggest impairment in the Mitochondrial Membrane Potential (MMP). In another study that investigated the mechanism of induced apoptosis by aluminum, increases in the activity of Caspase 3 and $\mathrm{P}-53$, and decreases in $B c l-2$ and $B A X$ factors were reported [24]. It appears that the mechanism of apoptosis induced by Almal or the inhibition of apoptosis by sodium benzoate is independent of changes in the mitochondrial membrane potential. The most protective mechanism of sodium benzoate is believed to be scavenging free radicals, such as hydroxyl groups [24].

Almal plays a significant role in the production of free radicals [28]. In addition, several studies have shown that the oxidative stress, induced by Almal, changes the lipid peroxidation and antioxidant enzymes activities [35, 36]. It has been suggested that the reduction in the mitochondrial membrane potential might not be necessary to induce apoptosis. Indeed, it may occur as a result of other signals to initiate the apoptosis pathway [37-39]. Therefore, it is believed that MMP impairment is not an early step in the initiation of apoptosis, as it might depend on cell types, other inducers and the type of fluorochrome marker used [40]. There are not many studies published on the effect of aluminum on mitochondrial membrane potential in mammalian cells, but recently one study suggested that aluminum reduces the membrane potential in lymphocytes [41].

Under physiological conditions, acetylcholinesterase is involved in the function of cholinergic neurons. Therefore, inhibition of acetylcholinesterase has been suggested as a therapeutic approach in the management of patients with $\mathrm{Al}$ zheimer's disease [42]. The effects of sodium benzoate on acetylcholinesterase in the aluminum toxicity model and its role in the improvement of Alzheimer's symptoms have previously been investigated [34]. The results suggest that the enzyme did not alter in PC-12 cells treated with either Almal or sodium benzoate. Further, this enzyme in patients with $\mathrm{AD}$ leads to strengthening of the acetylcholine messenger route and reduction of the cognitive impairment [43]. Based on the results of the current study, it can be concluded that sodium benzoate influences the activity of $\mathrm{AChE}$ and may have positive effects on the improvement of Alzheimer's symptoms. In future studies, besides measuring the $\mathrm{AChE}$ activity, its levels in the CSF or blood or both should also be measured. Upon our literature search and to the best of our knowledge, there is no previous report on the effect of sodium benzoate on $\mathrm{AChE}$ activity in PC-12 cell line. Therefore, this study may be the first report in this context.

Due to limited laboratory resources, we could not measure cytochrome $\mathrm{C}$ activity to differentiate cell death derived from 
mitochondrial versus non-mitochondrial dependent pathway, arising from the ROS levels and other oxidative stressors.

In addition to the measurement of cytochrome $\mathrm{C}$ activity, as stated above under the limitations, we recommend that future studies investigate the effect of sodium benzoate on the gene and protein expressions of mitochondrial respiratory chain complex. Besides measuring the AChE activity in future research, one should consider evaluating the AChE levels in the CSF or serum or both. Also, studying the rate of energy metabolism in similar cell lines and in animal models representing $\mathrm{AD}$ will help elucidate the protective effect of sodium benzoate in prevalent neurodegenerative disorders.

\section{Conclusions}

Based on the findings of this study, sodium benzoate exerts its protective effect against aluminum toxicity on cells through the inhibition of apoptosis. Both sodium benzoate and aluminum seem to impact similar targets for the $\mathrm{AChE}$ activity but with opposing outcomes. It also appears that the disruption of mitochondrial membrane potential has nothing to do with apoptosis induced by aluminum toxicity. Further, sodium benzoate is likely to relieve the symptoms of neurodegenerative diseases by lowering the incidence of neural cell death. The cellular and molecular mechanisms of this effect await future research.

\section{Ethical Considerations}

\section{Compliance with ethical guidelines}

This study was approved by the Ethics Committee of the University of Shiraz University of Medical Sciences (Ethical Code: IR.SUMS.REC.1394.S1116).

\section{Funding}

This investigation was financially supported by a grant from Shiraz University of Medical Sciences (Grant No.: \#: 94-01-103-10842).

\section{Author's contributions}

All authors were equally contributed in preparing this article.

\section{Conflict of interest}

The authors declared no conflict of interest.

\section{Acknowledgements}

The authors appreciate the instrumental facilities provided by Diagnostic Laboratory Sciences and Technology Research Center at Shiraz University of Medical Sciences. The authors wish to thank Mr. H. Argasi from Consultation Center for reviewing the manuscript.

\section{References}

[1] Silambanan S, Manikandan A, Palaneeswari S. Aluminium toxicity in chronic kidney disease patients on maintenance hemodialysis. Intl J Sci Res. 2015; 4(6):370-2.

[2] Jaishankar M, Tseten T, Anbalagan N, Mathew BB, Beeregowda KN. Toxicity, mechanism and health effects of some heavy metals. Interdiscip Toxicol. 2014; 7(2):60-72. [DOI:10.2478/intox-2014-0009] [PMID] [PMCID]

[3] Alexandrov PN, Pogue AI, Lukiw WJ. Synergism in aluminum and mercury neurotoxicity. Integr Food Nutr Metab. 2018; 5(3):1-7. [DOI:10.15761/IFNM.1000214] [PMID] [PMCID]

[4] Zeng KW, Fu H, Liu GX, Wang XM. Aluminum maltolate induces primary rat astrocyte apoptosis via overactivation of the class III PI3K/Beclin 1-dependent autophagy signal. Toxicol In Vitro. 2012; 26(2):215-20. [DOI:10.1016/j.tiv.2011.11.010] [PMID]

[5] Cannon JR, Greenamyre JT. The role of environmental exposures in neurodegeneration and neurodegenerative diseases. Toxicol Sci. 2011; 124(2):225-50. [DOI:10.1093/toxsci/kfr239] [PMID] [PMCID]

[6] Sood PK, Nahar U, Nehru B. Curcumin attenuates aluminum-induced oxidative stress and mitochondrial dysfunction in rat brain. Neurotox Res. 2011; 20(4):351-61. [DOI:10.1007/s12640-011-9249-8] [PMID]

[7] Rashedinia M, Saberzadeh J, Khosravi Bakhtiari T, Hozhabri S, Arabsolghar R. Glycyrrhizic acid ameliorates mitochondrial function and biogenesis against aluminum toxicity in PC12 cells. Neurotox Res. 2019; 35(3):584-93. [DOI:10.1007/s12640018-9967-2] [PMID]

[8] Li Y, Dai YB, Sun JY, Xiang y, Yang J, Dai SY, et al. Neuroglobin attenuates beta amyloid-induced apoptosis through inhibiting caspases activity by activating PI3K/Akt signaling pathway. J Mol Neurosci. 2016; 58(1):28-38. [DOI:10.1007/ s12031-015-0645-z] [PMID]

[9] Abramov AY, Canevari L, Duchen MR. $\beta$-amyloid peptides induce mitochondrial dysfunction and oxidative stress in astrocytes and death of neurons through activation of NADPH oxidase. J Neurosci. 2004; 24(2):565-75. [DOI:10.1523/JNEUROSCI.4042-03.2004] [PMID] [PMCID]

[10] Takeyama N, Matsuo N, Tanaka T. Oxidative damage to mitochondria is mediated by the Ca2+-dependent innermembrane permeability transition. Biochem J. 1993; 294(Pt 3):719-25. [DOI:10.1042/bj2940719] [PMID] [PMCID] 
[11] Cenini G, Voos W. Mitochondria as potential targets in Alzheimer disease therapy: An update. Front Pharmacol. 2019; 10:902. [DOI:10.3389/fphar.2019.00902] [PMID] [PMCID]

[12] Lennerz BS, Vafai SB, Delaney NF, Clish CB, Deik AA, Pierce KA, et al. Effects of sodium benzoate, a widely used food preservative, on glucose homeostasis and metabolic profiles in humans. Mol Genet Metab. 2015; 114(1):73-9. [DOI:10.1016/j.ymgme.2014.11.010] [PMID] [PMCID]

[13] Toth B. Lack of tumorigenicity of sodium benzoate in mice. Toxicol Sci. 1984; 4(3part1):494-6. [DOI:10.1093/ toxsci/4.3part1.494]

[14] Mahmoud GS, Sayed SA, Abdelmawla SN, Amer MA Positive effects of systemic sodium benzoate and olanzapine treatment on activities of daily life, spatial learning and working memory in ketamine-induced rat model of schizophrenia. Int J Physiol Pathophysiol Pharmacol. 2019; 11(2):21-30. [PMID] [PMCID]

[15] Beezhold BL, Johnston CS, Nochta KA. Sodium benzoate-rich beverage consumption is associated with increased reporting of adhd symptoms in college students a pilot investigation. J Atten Disord. 2014; 18(3):236-41. [DOI:10.1177/1087054712443156] [PMID]

[16] Oboh G, Adebayo AA, Ademosun AO, Olowokere OG Rutin restores neurobehavioral deficits via alterations in cadmium bioavailability in the brain of rats exposed to cadmium. Neurotoxicology. 2020; 77:12-9. [DOI:10.1016/j.neuro.2019.12.008] [PMID]

[17] Francis PT, Palmer AM, Snape M, Wilcock JK. The cholinergic hypothesis of Alzheimer's disease: A review of progress. J Neurol Neurosurg Psychiatry. 1999; 66(2):137-47. [DOI:10.1136/jnnp.66.2.137] [PMID] [PMCID]

[18] Bartus RT, Dean RL, Beer B, Lippa AS. The cholinergic hypothesis of geriatric memory dysfunction. Science. 1982; 217(4558):408-14. [DOI:10.1126/science.7046051] [PMID]

[19] Arabsolghar R, Saberzadeh J, Khodaei F, Abbasi Borojeni R, Khorsand M, Rashedinia M. The protective effect of sodium benzoate on aluminum toxicity in PC12 cell line. Res Pharm Sci. 2017; 12(5):391-400. [DOI:10.4103/1735-5362.213984] [PMID] [PMCID]

[20] Khodaei F, Rashedinia M, Heidari R, Rezaei M, Khoshnoud MJ. Ellagic acid improves muscle dysfunction in cuprizone-induced demyelinated mice via mitochondrial Sirt3 regulation. Life Sci. 2019; 237:116954. [DOI:10.1016/j. lfs.2019.116954] [PMID]

[21] Ellman GL, Courtney KD, Andres Jr V, Featherstone RM. A new and rapid colorimetric determination of acetylcholinesterase activity. Biochem Pharmacol. 1961; 7(2):88-90. [DOI:10.1016/0006-2952(61)90145-9]

[22] Bradford MM. Rapid and sensitive method for the quantitation of microgram quantities of protein utilizing the principle of protein-dye binding. Anal Biochem. 1976; 72(1-2):24854. [DOI:10.1016/0003-2697(76)90527-3]

[23] Johnson VJ, Kim SH, Sharma RP. Aluminum-maltolate induces apoptosis and necrosis in neuro-2a cells: Potential role for p53 signaling. Toxicol Sci. 2005; 83(2):329-39. [DOI:10.1093/toxsci/kfi028] [PMID]

[24] Griffioen KJS, Ghribi O, Fox N, Savory J, DeWitt DA. Aluminum maltolate-induced toxicity in NT2 cells occurs through apoptosis and includes cytochrome c release. Neurotoxicology. 2004; 25(5):859-67. [DOI:10.1016/j.neuro.2003.12.004] [PMID]

[25] Jana A, Modi KK, Roy A, Anderson JA, van Breemen RB, Pahan K. Up-regulation of neurotrophic factors by cinnamon and its metabolite sodium benzoate: Therapeutic implications for neurodegenerative disorders. J Neuroimmune Pharmacol. 2013; 8(3):739-55. [DOI:10.1007/s11481-013-9447-7] [PMID] [PMCID]

[26] Brahmachari S, Jana A, Pahan K. Sodium benzoate, a metabolite of cinnamon and a food additive, reduces microglial and astroglial inflammatory responses. J Immunol. 2009; 183(9):5917-27. [DOI:10.4049/jimmunol.0803336] [PMID] [PMCID]

[27] Yadav A, Kumar A, Das M, Tripathi A. Sodium benzoate, a food preservative, affects the functional and activation status of splenocytes at non cytotoxic dose. Food Chem Toxicol. 2016; 88:40-7. [DOI:10.1016/j.fct.2015.12.016] [PMID]

[28] Xu W, Li T, Gao L, Lenahan C, Zheng J, Yan J, et al. Sodium benzoate attenuates secondary brain injury by inhibiting neuronal apoptosis and reducing mitochondria-mediated oxidative stress in a rat model of intracerebral hemorrhage: Possible involvement of DJ-1/Akt/IKK/NFKB pathway. Front Mol Neurosci. 2019; 12:105. [DOI:10.3389/fnmol.2019.00105] [PMID] [PMCID]

[29] Park HW, Park EH, Yun HM, Rhim H. Sodium benzoatemediated cytotoxcity in mammalian cells. J Food Biochem. 2011; 35(4):1034-46. [DOI:10.1111/j.1745-4514.2010.00432.x]

[30] Noorafshan A, Erfanizadeh M, Karbalay-Doust S. Sodium benzoate, a food preservative, induces anxiety and motor impairment in rats. Neurosciences (Riyadh). 2014; 19(1):24-8. [PMID]

[31] Khoshnoud MJ, Siavashpour A, Bakhshizadeh M, Rashedinia M. Effects of sodium benzoate, a commonly used food preservative, on learning, memory, and oxidative stress in brain of mice. J Biochem Mol Toxicol. 2018; 32(2):e22022. [DOI:10.1002/jbt.22022] [PMID]

[32] Khodaei F, Kholghipour H, Hosseinzadeh M, Rashedinia M. Effect of sodium benzoate on liver and kidney lipid peroxidation and antioxidant enzymes in mice. J Reports Pharm Sci. 2019; 8(2):217-23. [DOI:10.4103/jrptps.JRPTPS_68_18]

[33] Gaur H, Purushothaman S, Pullaguri N, Bhargava Y, Bhargava A. Sodium benzoate induced developmental defects, oxidative stress and anxiety-like behaviour in zebrafish larva. Biochem Biophys Res Commun. 2018; 502(3):364-9. [DOI:10.1016/j.bbrc.2018.05.171] [PMID].

[34] Khasnavis S, Pahan K. Cinnamon treatment upregulates neuroprotective proteins Parkin and DJ-1 and protects dopaminergic neurons in a mouse model of Parkinson's disease. J Neuroimmune Pharmacol. 2014; 9(4):569-81. [DOI:10.1007/ s11481-014-9552-2] [PMID] [PMCID]

[35] Nixon RA. The role of autophagy in neurodegenerative disease. Nat Med. 2013; 19(8):983-97. [DOI:10.1038/nm.3232] [PMID]

[36] Chowra U, Yanase E, Koyama H, Panda SK. Aluminiuminduced excessive ROS causes cellular damage and metabolic shifts in black gram Vigna mungo (L.) Hepper. Protoplas- 
ma. 2017; 254(1):293-302. [DOI:10.1007/s00709-016-0943-5] [PMID]

[37] Webster KA. Mitochondrial membrane permeabilization and cell death during myocardial infarction: Roles of calcium and reactive oxygen species. Future Cardiol. 2012; 8(6):863-84. [DOI:10.2217/fca.12.58] [PMID] [PMCID]

[38] Cai J, Yang J, Jones DP. Mitochondrial control of apoptosis: The role of cytochrome c. Biochimica et Biophysica Acta (BBA) - Bioenergetics. 1998; 1366(1-2):139-49. [DOI:10.1016/ S0005-2728(98)00109-1]

[39] Wang C, Youle RJ. The role of mitochondria in apoptosis. Annu Rev Genet. 2009; 43:95-118. [DOI:10.1146/annurevgenet-102108-134850] [PMID] [PMCID]

[40] Panduri V, Weitzman SA, Chandel N, Kamp DW. The mitochondria-regulated death pathway mediates asbestosinduced alveolar epithelial cell apoptosis. Am J Respir Cell Mol Biol. 2003; 28(2):241-8. [DOI:10.1165/rcmb.4903] [PMID]

[41] Norenberg MD. Oxidative and nitrosative stress in ammonia neurotoxicity. Hepatology. 2003; 37(2):245-8. [DOI:10.1053/jhep.2003.50087] [PMID]

[42] Skarabahatava AS, Lukyanenko LM, Slobozhanina EI, Falcioni ML, Orlando P, Silvestri S, et al. Plasma and mitochondrial membrane perturbation induced by aluminum in human peripheral blood lymphocytes. J Trace Elem Med Biol. 2015; 31:37-44. [DOI:10.1016/j.jtemb.2015.02.002] [PMID]

[43] Holzgrabe U, Kapková P, Alptüzün V, Scheiber J, Kugelmann E. Targeting acetylcholinesterase to treat neurodegeneration. Expert Opin Therc Targets. 2007; 11(2):161-79. [DOI:10.1517/14728222.11.2.161] [PMID] 